\title{
Biodegradable polymer composites used in rapid prototyping technology by Melt Extrusion Polymers (MEP)
}

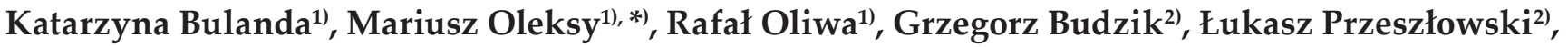 \\ Aleksander Mazurkow ${ }^{2)}$
}

DOI: dx.doi.org/10.14314/polimery.2020.6.2

\begin{abstract}
Appropriate selection of polymeric materials enables their wide application not only in machine construction elements, suspension and interior equipment of vehicles. Simultaneously with the development of new polymer materials, the processes of their processing developed. This also applies to incremental technologies. Rapid prototyping methods using 3D printers are largely based on various types of polymer materials. Currently, 3D printing is a well-known technique for producing functional elements, especially the Melt Extrusion Polymers (MEP) method, which is the oldest of the known techniques of spatial production. The main reason of the technology is designing and then manufacturing parts for many fields, including engineering, medicine, as well as the automotive and aviation industries. The article is a review of the literature on the use of composites based on thermoplastic polymers to develop new polymer materials used for 3D printing by MEP.
\end{abstract}

Keywords: Melt Extrusion Polymers (MEP), polymer materials and composites, 3D printing, filler.

\section{Biodegradowalne kompozyty polimerowe stosowane $w$ technologii szybkiego prototypowania metodą wytłaczania stopionego polimeru (MEP)}

Streszczenie: Odpowiedni dobór materiałów polimerowych umożliwia ich szerokie zastosowanie nie tylko w elementach konstrukcji maszyn, ale i zawieszenia oraz wyposażenia wnętrza pojazdów. Jednocześnie z opracowaniem nowych materiałów polimerowych nastapił rozwój procesów ich przetwórstwa. Dotyczy to również technologii przyrostowych. Metody szybkiego prototypowania z zastosowaniem drukarek 3D w dużej mierze wykorzystują różnego rodzaju materiały polimerowe. Obecnie druk 3D jest dobrze poznaną techniką wytwarzania elementów funkcjonalnych, szczególnie metodą osadzania stopionego polimeru Melt Extrusion Polymers (MEP), która stanowi najstarszą spośród poznanych technik wytwarzania przestrzennego. Jej głównym celem jest projektowanie, a następnie wytwarzanie części dla wielu dziedzin, m.in.: inżynierii, medycyny, a także przemysłu motoryzacyjnego, samochodowego oraz lotniczego. Artykuł stanowi przegląd literatury dotyczącej wykorzystania kompozytów na osnowie polimerów termoplastycznych do opracowania nowych materiałów polimerowych stosowanych do druku 3D metodą MEP.

Słowa kluczowe: Melt Extrusion Polymers (MEP), materiały i kompozyty polimerowe, drukowanie 3D, napełniacz.

Rapid prototyping technologies have been developed to accelerate the design process and manufacture of new models. The main purpose of the method is accurate visualization, which allows you to verify the correctness of the design and ensures rapid production of elements for various end applications, as well as rapid development of the

\footnotetext{
1) Rzeszow University of Technology, Department of Polymer Composites, al. Powstańców Warszawy 6, 35-959 Rzeszów, Poland.

2) Rzeszow University of Technology, Department of Mechanical Engineering, al. Powstańców Warszawy 8, 35-959 Rzeszów, Poland.

*) Author for correspondence: molek@prz.edu.pl
}

necessary tooling. Engineers also strive to receive a detail of satisfactory quality, which will allow them to increase competitiveness with a still short delivery time and low production costs [1-4]. Rapid prototyping (RP) technologies also have several disadvantages: limited dimensions of machine working chambers and high costs of equipment and materials [5]. The continuous development of RP technology aims to search for new ways to improve the speed, accuracy and reliability of rapid prototyping systems and to expand the range of materials for building parts, prototypes $[5,6]$.

ABS (acrylonitrile butadiene styrene) is the most commonly used material in Poland in the group of construction materials, followed by PLA (polylactide), polycarbonate (PC), polyamides (PA) and their composites [7]. At first, RP 
methods were focused only on unfilled polymers, which were then replaced or supplemented by increasingly newer polymer, ceramic and metallic composites. The use of polymer composites in RP technology allows to obtain a product with significantly better functional properties $[8,9]$.

Many RP technologies are known, but only a few of them have been used to make composites. These include: SLS/SLM (Selective Laser Sintering/Laser Melting), LENS (Laser Engineered Net Shaping), LOM (Laminated Object Manufacturing), SL (Stereolithography), FDM (Fused Deposition Modeling) and 3DP (Three-Dimensional Printing) [10-13].

\section{MELT EXTRUSION POLYMERS - MEP}

MEP technology, the oldest 3D printing technique, was introduced to the market by Stratasys Inc. from the USA in the early 90 's. It was originally developed for design applications and the creation of functional prototypes, but now it has gained considerable recognition in industry due to the simplicity of the process, affordable price and the ability to manufacture parts from a number of commonly used thermoplastics [14, 15].

MEP technology involves applying layers heated to about $0.5^{\circ} \mathrm{C}$ above the melting temperature of the material, which is then extruded through a nozzle of a certain diameter, so that it solidifies in about $0.1 \mathrm{~s}$ after extrusion, bonding cold with the previous layers $[10,16]$. The material used is in the form of a filament with a specific diameter, which allows the material to be dosed continuously into the melter chamber [17]. The quality of MEP machined parts depends mainly on the careful selection of process variables. That is why it is so important to know the parameters of MEP technology, which have a very large impact on the quality of the received parts [18, 19]. One of the key issues in the process is the selection of appropriate parameters to reduce production time and reduce the consumption of charge material while maintaining high dynamic mechanical properties [20, 21]. In the MEP method, it is necessary to maintain a constant head speed (this affects the total thickness of the element), nozzle speed and material extrusion speed, and the addition of a support structure for protruding elements $[10,16]$. Still, knowledge about the impact of many processing conditions on the characteristics of manufactured parts made of MEP is not sufficient [22], and therefore the consumption of energy and materials may be greater than planned, which results from human or machine errors occurring during the process [23].

\section{POLYMER MATERIALS USED FOR MEP PRINTERS}

MEP technology allows parts to be made of generally available thermoplastic polymers. All materials have some advantages, but also disadvantages and different requirements for processing parameters, such as application temperature. The material is most often chosen because of the properties of the raw material, planned final use of the obtained model, but also because of the type of disposable equipment, because MEP printers do not process all types of available raw materials [24]. The material intended for 3D printers should show several characteristic features: safety, non-toxicity, compatibility, sufficient material viscosity after melting (only in this way it is possible to bond layer by layer of the raw material), low glass transition temperature of the material, low melting temperature which results in lower energy consumption during the process $[2,25]$.

Developed by Stratasys Ltd., fused deposition modeling machines can produce parts from materials, thermoplastics, such as ABS, PLA, PC, PA, PEI (polyetherimide), ASA (acrylonitrile-styrene-acrylic), PC-ABS - mixed materials and many more [21, 26]. ABS and PLA have the greatest recognition and application so far. Currently, polylactide due to numerous advantages, among others biodegradability, biocompatibility and the possibility of material recycling has become a competitive material in relation to terpolymer. In addition, polylactide adheres well to the platform, does not deform during printing and requires a lower extrusion temperature compared to ABS [25]. However, the material is not free from defects, which include elongation at break less than $10 \%$, moisture sensitivity, poor strength and unsatisfactory surface quality. The material has limited use, because at temperatures above $60^{\circ} \mathrm{C}$ there may be a phenomenon of element warping $[2,3,27,28]$.

Determining the effect of process parameters on the mechanical properties of PLA used for 3D printing has been the subject of research by many scientists [29-35]. Zhao Y. and others [30] proved that the thickness of the material layer and the angle of printing the element by the MEP method have a significant impact on the product characteristics, especially the elastic properties and tensile strength. Scientists have received elements for research through rapid prototyping technology in various configurations of thickness $0.1 \mathrm{~mm}, 0.2 \mathrm{~mm}$ and $0.3 \mathrm{~mm}$, as well as the angle of application of plastic layers $0^{\circ}, 15^{\circ}, 30^{\circ}, 45^{\circ}, 60^{\circ}, 75^{\circ}$ and $90^{\circ}$. The authors examined the tensile strength of the obtained fittings, observing a decrease in tensile strength as the thickness of the PLA layer increased. They observed an increase in tensile strength as the printing angle increased. The best results, including the Young's modulus, were obtained for samples with a layer thickness of $0.1 \mathrm{~mm}$ with a printing angle of $90^{\circ}$. In addition, Rodriquez-Panes A. and others in their work [28] also proved that the mechanical properties of fittings made of PLA mainly depend on process variable technologies. Researchers have noticed that an important factor affecting the properties of shaped bodies, besides the height and orientation of the layer, is the filling density. Bonds between layers in PLA are very strong, the more layers the more this attribute increases, which is why parts made of polylactide using so called 3D printing show strength comparable to elements obtained by compression or injection pressing technologies. In addition to 
the layer thickness and filling density, Torres J. et al. [32] tested the effect of final treatment, i.e. heat treatment at $100^{\circ} \mathrm{C}$, on elements made of PLA using the MEP method. Regression analysis allowed to determine the impact of individual parameters on mechanical properties, and the results revealed that the optimization of the parameters of layer thickness and filling density shows significance in terms of improving material strength, while heat treatment has little effect on the results obtained. Ductility results significantly depend on the filling density and heat treatment.

The increase in the crystalline phase in the polymer has a beneficial effect on the properties of polymeric materials. For this reason, Wach R.A. and others in their work [33] presented the possibility of improving the mechanical properties of parts made of PLA by the MEP method by increasing the degree of crystallinity of the material. Most often, the polymer is processed in the lower limits of application temperature due to the possibility of material degradation, however, the use of higher temperatures enables a good interfacial connection in the material, thanks to which the obtained detail is of high quality. On this basis, scientists estimated $215^{\circ} \mathrm{C}$ as the most favorable temperature for processing polymer material, this value is a kind of compromise between degradation and satisfactory performance of the obtained element. Therefore, the additional element obtained is subjected to thermal annealing in order to obtain the highest possible degree of crystallinity of the material. The element obtained in this way is characterized by a higher degree of flexural strength by about $11-17 \%$ in relation to the parts not subjected to heat treatment.

Cuiffo M.A. and others in their work [26] performed a number of determinations, including Fourier transform infrared spectroscopy and photoacousitc FT-IR spectroscopy, X-ray photoelectron spectroscopy and Raman spectroscopy to determine the physicochemical properties of the polymer materials tested. It was found that the source material contains calcium carbonate, which is also present in the final product. In addition, MEP technology causes chemical changes in PLA, an increase in hydroxyl groups $-\mathrm{OH}$, which can be caused by absorbed moisture, as well as changes in the frequency of vibrations associated with $\mathrm{CH}_{3}, \mathrm{C}=\mathrm{O}, \mathrm{C}-\mathrm{O}$ - ligands. During 3D printing using the Melt Extrusion Polymers method, the PLA surface becomes more reactive and the structure of the polymer material is transformed, and therefore the possible range of temperatures used, melting characteristics and crystallization mechanism also changes.

Steinle P. in his work [35] examined the emission of gases that are generated during 3D printing by MEP. The obtained results allowed to state that during the printing of the PLA polymer element, the tested gas emissions were higher than those obtained during the production of parts from ABS. The measured emissions of the finest gases consisted of volatile droplets or small particles with a diameter of $100-300 \mathrm{~nm}$ iron and carbon black-like par- ticles. Detected emissions of volatile organic compounds were at $10 \mu \mathrm{g} / \mathrm{min}$ for polylactide.

\section{PLA-BASED POLYMER COMPOSITES USED IN RP TECHNOLOGY BY THE MEP METHOD}

Polylactide is often modified with other plastic polymers such as polycaprolactone (PCL), poly(ethylene glycol) (PEG), poly(butylene succinate) (PBS) or poly(butylene adipate-co-terephthalate) (PBAT). An interesting combination of polymers was presented by Haq R.H.A. and others in their work [36], where they described the possibility of obtaining composites for 3D printing by MEP method consisting of PLA and polycaprolactone (PCL) with different percentage of ingredients. Polycaprolactone - biodegradable polymer, showing interesting properties, above all good miscibility with other polymers. Researchers characterized the composite obtained and examined its mechanical properties: flexural strength and static tensile strength. They found that the presence of PLA caused an increase in the results of the Young's modulus, as well as material impact strength, and a decrease in flexural strength and flexural modulus in relation to PCL. The morphological properties of PLA/PCL composites examined by Fourier transform infrared spectroscopy showed that PCL and PLA spectra are only a mixture.

Haq R.H.A and others in their work [37] for better print effect plastified the PCL/PLA composite used in MEP technology with poly(ethylene glycol). The composite thus obtained was subjected to static tensile strength and impact strength determination. The results of these studies showed that the additive significantly improved tensile strength and impact strength.

In order to modify PLA, fillers are introduced into the polymer matrix, which are designed to increase the volume, weight of the composite, as well as reduce the price (inert fillers) or improve the mechanical and/or physicochemical properties (active fillers) of the composite. The fillers used most often for this purpose can be divided into inorganic, organic and synthetic. Commonly used fillers are inorganic powder mineral fillers, such as graphite, talc, titanium white, but also long and chopped glass fibers, carbon belonging to synthetic fillers.

The mechanical properties of printed parts obtained from PLA are lower compared to construction materials, e.g. reinforced with glass fibers. Therefore, scientists have attempted to modify this polymer by introducing additives, usually at the nanometer scale, into the polymer matrix.

Liu Z. et al. in their work [38] proposed modification of PLA by the addition of copper, wood, ceramic, aluminum and carbon fiber. The obtained results allowed to state that the introduced additives have a big impact on the results of tensile and flexural strength. Metallic powders, aluminum and copper resulted in increased strength, tensile and bending modulus compared to 
unfilled PLA. Details obtained as a result of mixing with ceramic fillers are characterized by the highest results of tensile strength and modulus of elasticity. In the case of the introduction of cellulose and carbon fibers, elements with lower mechanical properties were obtained in relation to fittings made of PLA.

Composites reinforced with both glass and carbon fibers are often the subject of research of many scientists from the world. However, the use of carbon fiber filling for composites intended for 3D printing is still rare. Heidari-Rarani M. and others in their work [39] proposed strengthening thermoplastics with the filler. Many parameters have been characterized, e.g. optimal carbon fiber diameter, processing parameters, increased fibermatrix binding by the addition of PVA [poly(vinyl alcohol)] solution, quick cooling of printed samples and simultaneous dosing of fibers and molten polymer. Analyzing the results, the researchers found that the addition of carbon fiber to the polymer matrix caused an increase of approximately 35\% in tensile strength and approximately $108 \%$ in flexural strength compared to unfilled PLA. The morphological analysis of the material showed that damage in carbon fiber reinforced plastic is mainly delamination, which induces the cracking of the polymer matrix, and the preparation of fibers through a PVA solution is very effective - the process allows increasing the bond between PLA and fibers. High-performance components made of composite can be used, among others, in the automotive industry or in robotics.

Among the many fillers used in the production of filament, additives containing carbon structures, such as nanotubes, stratified graphite, graphene, which can successfully replace the previously presented carbon and even glass fibers dominate. For this reason, PLA's additions widely described in the available literature are graphene and carbon nanotubes (CNTs).

Yang L. and others in their work [40] presented the possibility of obtaining a polymer filament filled with carbon nanotubes. The introduction of a filler into the PLA matrix has a significant impact on the mechanical properties and electrical conductivity of the material. Scientists have proven that the introduction of a $6 \%$ additive increases tensile strength by $64.12 \%$ and bending strength by $29.29 \%$. They obtained the electrical resistivity in the range $10^{12} \Omega / \mathrm{m}^{2}$ to $10^{2} \Omega / \mathrm{m}^{2}$ for various CNT contents from $0 \%$ to $8 \%$ of filling. In contrast, Camargo J.C. and others [41] proved that graphene-filled PLA also has very good mechanical properties. The tensile strength and flexural strength increases with the increase in the amount of additive, as well as the thickness of the layer, the best results were obtained for $78 \%$ filling and $0.27 \mathrm{~mm}$ layer thickness. The impact strength of the composition was also examined, which is also dictated by the amount of filling and the thickness of the layers, the best result was obtained by a composite with $50 \%$ filling and a layer thickness of $0.2 \mathrm{~mm}$. An interesting solution was proposed by Iwanov E. and others in their work [34], where they used graphene nanoplates (GNP) and multi-walled carbon nanotubes (MWCNTs), the authors described the possibility of obtaining a hybrid polymer composite with the addition of both fillers at the same time. Scientists obtained an even dispersion of the filler in the PLA polymer matrix, which was confirmed by studies of transmission electron microscopy, scanning electron microscopy and Raman spectroscopy. Thanks to the obtained microstructure, the heat and electron flow were facilitated, and therefore the thermal properties of the composite increased. In addition, the authors observed a synergy effect in materials containing bi-filler with a mass ratio of $3 \% \mathrm{GNP} / 3 \%$ CNT and $1.5 \% \mathrm{GNP} / 4.5 \% \mathrm{CNT}$, the compositions show higher electrical conductivity compared to other systems containing other concentration combinations. The thermal conductivity increases with the increase in the addition of graphene nanoplates to the polymer matrix. The introduction of carbon structure into the polymer allows obtaining a composite with modified mechanical, electrical and thermal properties, so it has become possible to significantly expand the use of MEP elements made of PLA-based composites.

Hemp powder turned out to be an interesting addition to thermoplastics, which is one of the organic, natural fillers. The authors of Coppola B. and others introduced various concentrations of 1, 3 and $5 \%$ by volume of material into the polymer matrix [42]. The rheological properties of the obtained composite were determined, stating that the viscosity of the polymer decreases with a smaller amount of additive in the material. The composite showed a much higher elastic modulus compared to the unfilled material, the modulus increases with increasing filler content, and dynamic mechanical analysis showed an increase in the storage modulus when increasing the volume of hemp. The best results were obtained by the composite with $5 \%$ volume filling.

Plastics usually show resistance to salts, bases and acids, but parts made of PLA are biodegradable, which can cause a range of reactions, primarily between the surface of the element and the environment. In recent years, many researchers have focused on designing material with increased corrosion properties that still retain good mechanical properties.

Arun K. and others in their work [43] described the possibility of using copper coatings on polylactide parts produced in the MEP process used in the electrotechnical industry. Tests confirmed the increase in corrosion resistance of copper electrodeposited coatings in sea water, as well as the increase in Vickers hardness.

Generally, the agents used to dye polymer materials are insoluble pigments or plastics soluble dyes, which are selected taking into account color stability, physiological properties and cost of use [44].

The authors of Valerga A.P. et al. [45] examined that the viscosity and density of pigments have a great influence on the adhesion and stability of printing. 
The authors of Mico-Vicent B. and others developed composites with the addition of metallic pigment used in the automotive industry and observed the effect of the presence of metallic pigment on improving the surface quality of printed parts of machines [46].

In the next publication, the authors [3] examined the effect of adding pigment to PLA on the change in polymer viscosity. On the basis of the results obtained, they found that the addition of pigment to PLA reduces the viscosity and hence better surface quality of the printed element is obtained.

Valerga A.P. and others in their work [27] observed a significant improvement in the surface quality of elements made of PLA by the MEP method as a result of immersion in organic solvents such as ethyl acetate, tetrahydrofuran, dichloromethane and chloroform. Particularly good results of thermal, structural and crystallinity properties were obtained by using chloroform as the solvent. The resulting changes prevent the degradation of the material and allow to eliminate the glass transition phase and achieve an improvement in surface roughness by about $97 \%$.

Another article [47] presents a quick, economical and easy to use chemical treatment of the element, which is based on the possibility of using dichloromethane and sodium hydroxide to finish the surface of the element. The results obtained on a $3 \mathrm{D}$ laser microscope allow to state that the use of dichloromethane vapors gives better results (reduction of roughness results by $88 \%$ ) in comparison to $\mathrm{NaOH}$.

\section{APPLICATION OF BIODEGRADABLE POLYMER COMPOSITES MADE USING THE MELT EXTRUSION POLYMERS TECHNIQUE}

Polylactide is most often used for the production of various types of bottles and disposable packaging. The material is fully biodegradable, therefore it is possible to decompose it in the soil during about 80 days in commercial conditions of a composting plant, this is an important advantage of the material, because other polymer materials need more than 100 days for degradation [48].

The automotive, aviation and robotics industries are areas where large quantities of thermoplastics are processed using 3D printing. In addition, it is possible to modify polymeric materials, among others through the use of metallic pigments, which substantially improve the appearance of parts and ensure the proper gloss of the product [49]. Composite materials are usually applied to produce body parts such as bumpers, fenders, seats and individual parts of machinery and equipment. Scientists presented the possibility of using PLA by the MEP method to produce polymer composites reinforced with carbon fiber. The composite is widely used, among others, to obtain structural panels that are characterized by high strength and stiffness, as well as low weight of parts. In addition, the material can be produced in the form of structurally complex elements, geometrically complex shapes [49-51].

This material was also used in medicine, e.g. for the production of surgical sutures, dental implants, abutments and screws for connecting broken limbs. Recently, publications have also been created that describe the possibility of using polymer material using MEP technology in personalized medicine.

Tagami T. and others in their work [52] received through the MEP method composite tablets consisting of a poly(vinyl alcohol) drug containing calcein and a PVA or PLA filler. In this way, scientists received various types of tablets PVA/PLA and PVA/PVA. The conducted research was successful, and thanks to the use of polymer filling, the release of drugs is effectively controlled. The compositions of PVA/PLA and PVA/PVA differ from each other because PLA is poorly water-soluble and forms a stable fill, whereas PVA is a water-soluble polymer and can be a temporary fill. The rate of drug release is closely related to the surface of the exposed drug component. The presented innovation is important for individualized therapy, because through 3D printing it has become possible to obtain composite tablets on demand, which differ in the release characteristics of individual drugs.

Fu J. [53] in his publication described the preparation of personalized vaginal rings with progesterone from PLA. The rings are a gynecological device and are used to deliver drugs with a specific dose, size and shape. Progesterone was mixed with poly(ethylene glycol) and then added to the PLA/PCL mixture (ratio of polymers in the mixture $8: 2$ ). The ingredients were hot melted to obtain the filament, which was then used in the MEP process. " $\mathrm{O}$ ", " $\mathrm{Y}$ " and " $\mathrm{M}$ " rings were obtained, the presence of amorphous female hormone in the product was found by X-ray powder diffraction and differential scanning calorimetry. Thermal gravimetric analysis showed that progesterone did not decompose in the preparation. The $\mathrm{O}$-shaped ring dissolved more compared to the others due to the higher surface area to volume ratio. Thanks to the use of rings, it is possible to control the drug by diffusion for over 7 days. The presented research results may increase the range of using $3 \mathrm{D}$ printing.

\section{SUMMARY}

MEP is the most commonly used 3D printing method because of inexpensive polymer filaments. This technique allows the use of various polymeric materials and their composites. Due to its biodegradable properties, PLA is an interesting material and is very popular. Until recently, this material was one of the less used polymers due to its poor thermal and mechanical resistance. But thanks to constant modifications and research, the area of its application is significantly increased.

To sum up, rapid MEP prototyping methods are widely used in many fields of technology and medicine. One of the basic advantages of this technology is the possibility of making prototypes with complex internal and external geometry 
in any number in a short time. Therefore, to meet specific orders, the demand for newer and newer polymer materials with interesting properties is constantly increasing.

\section{REFERENCES}

[1] Medellin-Castillo H.I., Zaragoza-Siqueiros J.: Chinese Journal of Mechanical Engineering 2019, 32, 53. https://doi.org/10.1186/s10033-019-0368-0

[2] Baran E.H., Erbil H.Y.: Colloids and Interfaces 2019, 3, 43.

https://doi.org/10.3390/colloids3020043

[3] Valerga A., Batista M., Salguero J., Girot F.: Materials 2018, 11, 1322. https://doi.org/10.3390/ma11081322

[4] Siemiński P., Budzik G.: „Techniki przyrostowe, druk 3D, drukarki 3D", Oficyna Wydawnicza Politechniki Warszawskiej, Warszawa 2015.

[5] Kampa A.: Selected Engineering Problems 2012, 3, 93.

[6] Pham D.T., Gault R.S.: Journal of Machine Tools \& Manufacture 1998, 38, 1257. https://doi.org/10.1016/S0890-6955(97)00137-5

[7] Dudek P.: Archives of Metallurgy and Materials 2013, 58, 1415.

http://dx.doi.org/10.2478/amm-2013-0186

[8] http://pclab.pl/art57509.html

[9] http://biotechnologia.pl/biotechnologia/drukowanie-3d-rewolucja-rowniez-wmedycynie

[10] Lee S.C., Kim S.G., Kim H.J., Ahn S.H.: Journal of Materials Processing Technology 2007, 187-188, 627. https://doi.org/10.1016/j.jmatprotec.2006.11.095

[11] Kumar S., Kruth J.P.: Materials and Design 2010, 31, 850.

[12] Karalekas D., Antoniou K.: Journal of Materials Processing Technology 2004, 153-154, 526. https://doi.org/10.1016/j.jmatprotec.2004.04.019

[13] Yan Y., Li S., Zhang R. et al.: Tsinghua Science Technology 2009, S1 (14), 1. https://doi.org/10.1016/S1007-0214(09)70059-8

[14] Boschetto A., Bottini L., Veniali F.: Additive Manufacturing 2016, 12, 334. http://dx.doi.org/10.1016/j.addma.2016.05.008

[15] Mohamed O.A., Masood S.H., Bhowmik J.L.: Materials and Manufacturing Processes 2016, 31, 1983. http://dx.doi.org/10.1080/10426914.2015.1127955

[16] Pandey P.M.: Materials Science Forum 2012, 101-109, 710.

http://dx.doi.org/10.4028/www.scientific.net/ MSF.710.101

[17] Caban J., Szala M., Kęsik J., Czuba Ł.: Eksploatacja $i$ Testy 2017, 6, 573.

[18] Durgun I., Ertan R.: Rapid Prototyping Journal 2014, 20, 228. http://dx.doi.org/10.1108/RPJ-10-2012-0091

[19] Mahomed O.A., Masood S.H., Bhowmik J.L.: International Journal on Future Revolution in Computer Science \& Communication Engineering 2015, 1 (3), 42.
[20] Mohamed O.A., Masood S.H., Bhowmik J.L.: Applied Mathematical Modelling 2016, 40, 10052. http://dx.doi.org/10.1016/j.apm.2016.06.055

[21] Górski F., Wichniarek R., Kuczko W.: Journal of Machine Engineering 2014, 3, 14.

[22] Mohamed O.A., Masood S.H., Bhowmik J.L., Somers A.E.: Journal of Manufacturing Processes 2017, 29, 149. http://dx.doi.org/10.1016/j.jmapro.2017.07.019

[23] Song R., Telenko C.: Journal of Cleaner Production 2017, $148,895$. http://dx.doi.org/10.1016/j.jclepro.2017.01.171

[24] Beniak J., Krizan P., Matus M., Sajgalik M.: MATEC Web of Conferences 2018, 157, 06001. https://doi.org/10.1051/matecconf/201815706001

[25] Dudek P., Rapacz-Kmita A.: Archives Metallurgy and Materials 2016, 61, 891. https://doi.org/10.1515/amm-2016-0151

[26] Cuiffo M.A., Snyder J., Elliott A.M. et al.: Applied Sciences-Basel 2017, 7, 579. https://doi.org/10.3390/app7060579

[27] Valerga A.P., Batista M., Fernandez-Vidal S.R.: Polymers 2019, 11, 566. https://doi.org/10.3390/polym11030566

[28] Rodriguez-Panes A., Claver J., Camacho A.M.: Materials 2018, 11, 1333. https://doi.org/10.3390/ma11081333

[29] Yang L., Li S., Li Y. et al.: Journal of Materials Engineering and Performance 2019, 28, 169. https://doi.org/10.1007/s11665-018-3784-X

[30] Zhao Y., Chen Y., Zhou Y.: Materials \& Design 2019, 181, 108089. https://doi.org/10.1016/j.matdes.2019.108089

[31] Altan M., Eryildiz M., Gumus B., Kahraman Y.: Materials Testing 2018, 60, 471. https://doi.org/10.3139/120.111178

[32] Torres J., Cotelo J., Karl J., Gordon A.P.: JOM 2015, 67, 1183. https://doi.org/10.1007/s11837-015-1367-y

[33] Wach R.A., Wolszczak P., Adamus-Wlodarczyk A.: Macromolecular Materials and Engineering 2018, 303, 1800169.

[34] Ivanov E., Kotsilkova R., Xia H. et al.: Applied SciencesBasel 2019, 9, 1209. https://doi.org/10.3390/app9061209

[35] Steinle P.: Journal of Occupational and Environmental Hygiene 2016, 13, 121. https://doi.org/10.1080/15459624.2015.1091957

[36] Haq R.H.A., Rahman M.N.A., Ariffin A.M.T. et al.: IOP Conference Series: Materials Science and Engineering 2017, 226, 012038.

[37] Haq R.H.A, Marwah O.M.F., Rahman M.N.A. et al.: International Journal of Integrated Engineering: Special issue Mechanical Engineering 2018, 10, 187. http://dx.doi.org/10.30880/ijie.2018.10.05.028

[38] Liu Z., Lei Q., Xing S.: Journal of Materials Research and Technology 2019, 8, 3741. https://doi.org/10.1016/j.jmrt.2019.06.034 
[39] Heidari-Rarani M., Rafiee-Afarani M., Zahedi A.M.: Composites Part B: Engineering 2019, 175, 107147. https://doi.org/10.1016/j.compositesb.2019.107147

[40] Yang L., Li S., Zhou X. et al.: Synthetic Metals 2019, 253, 122. https://doi.org/10.1016/j.synthmet.2019.05.008

[41] Camargo J.C., Machado A.R., Almeida E.C. et al.: International Journal of Advanced Manufacturing Technology 2019, 103, 2423. https://doi.org/10.1007/s00170-019-03532-5

[42] Coppola B., Garofalo E., Di Maio L. et al.: AIP Conference Proceedings 2018, 1981, 020086. https://doi.org/10.1063/1.5045948

[43] Arun K., Aravindh K., Raja K. et al.: Materials TodayProceedings 2018, 5, 13107. https://doi.org/10.1016/j.matpr.2018.02.299

[44] Piekarska E.: Przetwórstwo tworzyw 2009, 12 (3), 98.

[45] Valerga A.P., Batista M., Puyana R. et al.: Procedia Manufacturing 2017, 13, 924. https://doi.org/10.1016/j.promfg.2017.09.161

[46] Mico-Vicent B., Perales E., Huraibat K. et al.: Materials 2019, 12, 1423. https://doi.org/10.3390/ma12091423

[47] Yifan J., Wan Y., Liu Z.: MATEC Web of Conferences 2017, 95, 05001.

http://dx.doi.org/10.1051/matecconf/20179505001

[48] Topiarzova R., Cablik V.: Inżynieria Mineralna 2011, 12 (2), 89.

[49] Ahmed S.W., Hussain G., Al-Ghamdi K.A., Altaf K.: Journal of Thermoplastic Composite Materials 2019. https://doi.org/10.1177/0892705719869407

[50] Li Y., Gao S., Dong R.: Journal of Materials Engineering and Performance 2018, 27, 492. https://doi.org/10.1007/s11665-017-3065-0

[51] Araujo H., Leite M., Ribeiro A.M.R. et al.: Frattura ed Integrità Strutturale 2019, 13 (49), 478. https://doi.org/10.3221/IGF-ESIS.49.45

[52] Tagami T. Nagata N., Hayashi N. et al.: International Journal of Pharmaceutics 2018, 543, 361. https://doi.org/10.1016/j.ijpharm.2018.03.057

[53] Fu J., Yu X., Jin Y.: International Journal of Pharmaceutics 2018, 539, 75.

https://doi.org/10.1016/j.ijpharm.2018.01.036

Received 30 I 2020. 